ENTREPRENEURSHIP AND SUSTAINABILITY ISSUES

ISSN 2345-0282 (online) http://jssidoi.org/jesi/

2021 Volume 8 Number 3 (March)

http://doi.org/10.9770/jesi.2021.8.3(26)

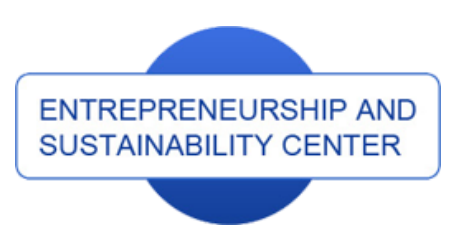

Publisher
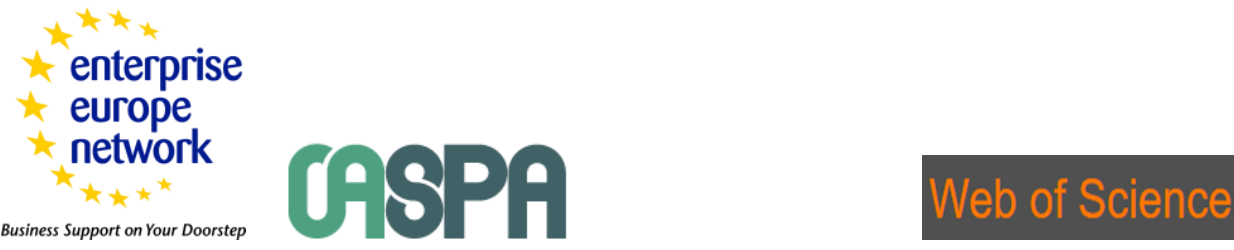

http://jssidoi.org/esc/home

Business Support on Your Doorstep

1 Clarivate

Analytics

\title{
LEGAL ASPECTS OF MIGRATION REGULATION AS A FACTOR OF NATIONAL SECURITY
}

\author{
Kostiantyn Buhaichuk ${ }^{1 *}$, Nataliia Varenia ${ }^{2}$, Vitalii Khodanovych ${ }^{3}$, Maryna Kriepakova ${ }^{4}$, \\ Valentyn Seredynskyi ${ }^{5}$ \\ ${ }^{1 * 4}{ }^{*}$ Kharkiv National University of Internal Affairs, Lieutenant Colonel of Police, Lev Landau Avenue, 27, Kharkiv, 61000, Ukraine \\ ${ }^{2,3}$ National Academy of Security Service of Ukraine, 22, Maksymovycha str., Kyiv, 03022, Ukraine \\ ${ }^{5}$ Investigative Department of the DVP GUNP in Dnipropetrovsk region, Troitskaya square, 2a, Dnipro, 49000, Ukraine
}

E-mail: ${ }^{1^{*}}$ buhaichuk@i.ua (Corresponding author)

Received 15 March 2020; accepted 8 January 2021; published 30 March 2021

\begin{abstract}
It has been proven that international migration is a global challenge to the national security of each country. The statistical analysis of migration processes in Ukraine has been carried out. Special features of legal regulation of migration flows in Ukraine have been considered. Migration control concerning transit migration in Ukraine is mainly related to the system of restrictions and measures of responsibility for non-compliance with established norms, and at the same time it is more important to ensure the legal stay of foreign citizens in the country, proper legal regulation of their accounting. Instead, Ukrainian case law and judgments of the European Court of Human Rights concerning Ukraine indicate existing violations in the procedure of state protection of the rights and freedoms of foreigners and stateless persons, which they are endowed with in accordance with international standards and national legislation while in Ukraine. One of the problems of migration control in Ukraine is the imperfection of the procedure for registration of citizens at the place of residence, which does not meet the state need to control the processes of population movement and migration within the country. Currently, the basis for registration is not the fact of living in a dwelling, but rather the right to reside in it, as the registration procedure involves the submission of supporting documents for such right. Moreover, living of citizens without registration of residence is an offense and entails the occurrence of administrative liability, while living outside the place of registration is legal.
\end{abstract}

Keywords: national security; migration flows; migration control; administrative responsibility; transit migration

Reference to this paper should be made as follows: Buhaichuk, K., Varenia, N., Khodanovych, V., Kriepakova, M., Seredynskyi, V. 2021. Legal aspects of migration regulation as a factor of national security, 8(3), 402-419. http://doi.org/10.9770/jesi.2021.8.3(26)

JEL Classifications: F35, F42 


\section{ENTREPRENEURSHIP AND SUSTAINABILITY ISSUES}

ISSN 2345-0282 (online) http://jssidoi.org/jesi/

2021 Volume 8 Number 3 (March)

http://doi.org/10.9770/jesi.2021.8.3(26)

Make your research more visible, join the Twitter account of ENTREPRENEURSHIP AND SUSTAINABILITY ISSUES: @Entrepr69728810

\section{Introduction}

Modern migration policy is mainly focused on eliminating threats related to security, primarily national, as well as personal security (citizens and newly arrived members of the immigration society), especially when it comes to such a subdivision of migration policy as the policy of adaptation of immigrants, which, albeit at a slow pace, but still developing in modern recipient countries of migrants. However, with successful cooperation in the regulation of migration processes, both with traditional and preventive measures, we can talk about combating the threats posed by the intensification of uncontrolled processes of international migration for security at the international (global) level.

The unparalleled importance of the issue under study is also confirmed by the content of the Association Agreement between Ukraine, on the one hand, and the European Union, the European Atomic Energy Community and their member states, on the other, which stipulates the importance of joint management of migration flows between territories and and a comprehensive dialogue on all issues in the field of migration, including illegal migration, legal migration, smuggling and trafficking in human beings, as well as the inclusion of problematic issues in national strategies for the economic and social development of migrant regions.

The special importance of migration control problems is also reflected in the national legislation by the fact that in accordance with the provisions of the Constitution of Ukraine only the laws of Ukraine determine the principles of regulation of demographic and migration processes, as well as the formation and operation of free and other special zones that have an economic or migration regime different from the general one. In our opinion, it is with this that the need for scientific studies in the relevant field, the development of scientific tools, clear legal categories, the conceptual framework of the relevant processes is related.

The purpose of the paper is a theoretical justification, development of scientific and methodological principles and practical solutions focused on improving the system of regulation of international migration in the context of globalization.

\section{Literature Survey}

As an economic category, international migration is a direct manifestation of the existence of the international (world) labor market, which is developing due to the uneven distribution of labor resources between countries.

Personel is recruited in countries where the demand for labor of the appropriate level of education and with the necessary skills and professional competencies exceeds its supply. In the event that an employee is unable to realize his or her potential, he or she seeks to move to a country where there is a vacancy commensurate with his or her level of professional competence. If a country is unable to provide adequate jobs for workers in the national labor market, there is a phenomenon of outflow of personnel.

The intensification of migration processes in the world economy is due to several reasons:

1) the tendency to increased contrast in the levels of economic and social development of exporting and importing countries of labor and population (Tymchyk (2014));

2) the growth of international capital movement and the functioning of transnational corporations that promote the union of labor and capital (Turetska (2018));

3) demographic crisis in developed countries, which is manifested in a reduction in the number of able-bodied people and an increase in the elderly (Vasylchenko (2014));

4) the presence of a large number of low-prestige jobs in services, health care, construction, agriculture, etc. 
ENTREPRENEURSHIP AND SUSTAINABILITY ISSUES

ISSN 2345-0282 (online) http://jssidoi.org/jesi/

2021 Volume 8 Number 3 (March)

http://doi.org/10.9770/jesi.2021.8.3(26)

Make your research more visible, join the Twitter account of ENTREPRENEURSHIP AND SUSTAINABILITY ISSUES: @Entrepr69728810

where the natives are reluctant to work (Levenets (2017))

5 ) the presence and intensity of information communications between countries or their absence (Reznik, et. al. (2020); Chehabeddine \&Tvaronavičienè (2020));

6) interethnic, religious, political problems, etc. (Hrabylnikov (2015); Lincényi, \& Laczko (2020)).

In scientific papers, regulations, you can find different interpretations of the concept of labor migration (Hula, (2018)). In the most general sense, labor migration is considered as the movement of population outside certain territories within the country or abroad due to changes in employment and residence.

As a social phenomenon, migration includes three parameters: change of coordinates of his or her location by a person (mobility factor), intentions of a person to improve his or her material and social condition (need factor) and attempts of a person to settle in a new place and consider it his or her "second home" (stability factor).

In the scientific literature, in the study of the migration regime of stay of foreign citizens and stateless persons in Ukraine the promising components are the following (Belevtseva, 2019):

- legal regime of "transnational corridors" and transit of foreign citizens through the territory of Ukraine;

- legal standing of compatriots who voluntarily relocate from abroad and other foreign citizens temporarily residing in Ukraine;

- legal regime of border areas.

In this study, the issues of migration control are subject to analysis, namely, by keeping records of foreign citizens and stateless persons. Therefore, our study will not relate to the regime of border areas.

Based on the study and analysis of the literature on the subject of the publication, it can be argued that the relationship between international migration and security issues remain poorly studied today, in contrast to the issues of migration processes themselves and security issues, which have long been considered mainly in the military dimension.

\section{Methods}

The theoretical-methodological basis of the paper are the basic factors of economics. Various study methods were used to solve the set tasks, in particular, system analysis (for theoretical-methodological substantiation of factors and consequences of migration); graphic analysis (to assess the dynamics of international labor migration); statistical analysis (to calculate the balance of migration, gross migration, coefficients of departure, arrival and migration turnover); grouping.

The accuracy of the study results is provided by a comprehensive use of general and special scientific methods of cognition. The methodological basis is a dialectical general scientific method of cognition, which was used in the study of the development of doctrine of control activities in the area of migration. The method of semantic analysis was used to clarify the content of such concepts as "migration", "control", "migration control", "registration", "accounting", "verification", "passport", "form of control", "method of control" , etc., and the formal-logical method was used in distinguishing similar concepts. Modeling and forecasting method was used when developing provisions for reforming the procedure for registration of citizens at the place of residence or stay. Methods of analysis and synthesis were used in the development of proposals to improve the legislation. The above methods were used in the study with the purpose of ensuring its comprehensiveness. 


\section{ENTREPRENEURSHIP AND SUSTAINABILITY ISSUES}

ISSN 2345-0282 (online) http://jssidoi.org/jesi/

2021 Volume 8 Number 3 (March)

http://doi.org/10.9770/jesi.2021.8.3(26)

Make your research more visible, join the Twitter account of ENTREPRENEURSHIP AND SUSTAINABILITY ISSUES: @Entrepr69728810

The theoretical foundations of the study were laid down by the fundamental achievements of scientists in the field of general theory of state and law, management theory, constitutional, administrative law and process (justice) and other branches of law formulated in the works of specialists, as well as encyclopedic legal literature.

The normative basis of the work is the Constitution of Ukraine, Laws of Ukraine, acts of the President of Ukraine, the Cabinet of Ministers of Ukraine, central executive bodies, international normative legal acts, the binding nature of which has been approved by the Verkhovna Rada of Ukraine.

The empirical basis of the study consists of law enforcement acts of government entities, court decisions, reference and statistical materials, etc.

\section{Results}

While analyzing the so-called transit migration, it should be noted that in Ukraine control measures are mainly related to the system of restrictions and liability for non-compliance with established norms. At the same time, in our opinion, it is more important to ensure the legal stay of foreign citizens on the territory of the state, so the issue of their registration, ensuring their rights and freedoms, which they are entitled to in accordance with international standards and national legislation when in Ukraine is more significant. Here it is also necessary to refer to the definition of "legal migration".

The legislation does not define this, but gives the definition of "illegal migrant", i.e., a foreigner or a stateless person who have crossed the state border outside checkpoints or at checkpoints, but with the avoidance of border control and did not immediately apply for refugee status or asylum in Ukraine, as well as a foreigner or a stateless person who legally arrived in Ukraine, but after the expiration of the period of their stay lost the grounds for further stay and evade leaving Ukraine (Law of Ukraine 'On the Legal Status of Foreigners and Stateless Persons' (2011)).

Accordingly, a foreigner, if he or she lives in Ukraine and does not meet the standard criteria, is a legal migrant. In general, the administrative and legal status of foreign citizens and stateless persons is established by the Law of Ukraine "On the Legal Status of Foreigners and Stateless Persons", the Convention on the Status of Refugees, the Convention on the Status of Stateless Persons, the Declaration of the Human Rights as regards the persons who are not the citizens of the country, in which they reside, and other laws and regulations.

The law defines a number of grounds for the stay of foreigners and stateless persons on the territory of Ukraine (Law of Ukraine 'On the Legal Status of Foreigners and Stateless Persons' (2011)).

Firstly, foreigners and stateless persons may, in accordance with the Law of Ukraine 'On Immigration' (2001), immigrate to Ukraine for permanent residence. The above law determines immigration as arrival in Ukraine or stay in Ukraine of foreigners and stateless persons for permanent residence in accordance with the order established by the law (Article 1 of the Law "On Immigration").

Secondly, foreigners and stateless persons may be recognized as refugees or granted asylum in Ukraine, in which case they are considered to be permanent residents of Ukraine, as evidenced by a refugee certificate.

Thirdly, there are foreigners and stateless persons who came to Ukraine to participate in the implementation of international technical assistance projects, in order to preach religious beliefs, to participate in the activities of branches, offices, representative offices and other structural units of public (non-governmental) organizations of foreign countries, for carrying out cultural, scientific, educational activity on the grounds and in the order 


\section{ENTREPRENEURSHIP AND SUSTAINABILITY ISSUES}

ISSN 2345-0282 (online) http://jssidoi.org/jesi/

2021 Volume 8 Number 3 (March)

http://doi.org/10.9770/jesi.2021.8.3(26)

Make your research more visible, join the Twitter account of ENTREPRENEURSHIP AND SUSTAINABILITY ISSUES: @Entrepr69728810

established by the international agreements of Ukraine or special programs, for the purpose of education or employment, for work as the correspondent or the representative of foreign mass media. Such persons receive a temporary residence permit and are considered to be legally present on the territory of Ukraine for the period of validity of the circumstances that caused the stay.

Fourthly, foreigners and stateless persons who arrived in Ukraine for the purpose of family reunification with persons who are citizens of Ukraine, or who while staying legally on the territory of Ukraine married Ukrainian citizens and received temporary residence permit are considered to be legally present on the territory of Ukraine for the period prior to obtaining an immigration permit (Article 4 of the Law "On the Legal Status of Foreigners and Stateless Persons").

Thus, foreigners and stateless persons can stay in our country for different periods (both permanently and temporarily) and for different purposes, the legal regulation of their status allows to distinguish three groups of persons:

1) persons permanently residing on the territory of Ukraine;

2) persons temporarily residing on the territory of Ukraine;

3) refugees and asylum seekers.

Consequently, it is just in this order that the legal regulation of their registration by the national law will be studied. However, due to the fact that the mechanisms of registration and control of persons permanently residing in Ukraine coincide with those applied to persons temporarily staying in Ukraine, their analysis will be conducted simultaneously.

Permanent residence of foreigners in Ukraine is related to such concept as "immigration" and is regulated by the Law of Ukraine "On Immigration" (2001). Immigration permit is issued within the immigration quota set by the Cabinet of Ministers of Ukraine for the following categories of immigrants:

1) workers of science and culture, whose immigration meets the interests of Ukraine;

2) highly qualified specialists and workers, the urgent need for which is considerable for the economy of Ukraine;

3) persons who have made a foreign investment in the economy of Ukraine in a foreign convertible currency in the amount of not less than 100 (one hundred) thousand US dollars;

4) persons who are full brothers or sisters, grandparents, grandson or granddaughter of citizens of Ukraine;

5) persons who were previously citizens of Ukraine;

6) parents, husband (wife) of an immigrant and his minor children;

7) persons who have continuously resided on the territory of Ukraine for three years from the date of establishing their status as a victim of human trafficking;

8) persons who have served in the Armed Forces of Ukraine for three or more years.

So, for example, for 2019 the government established the following quotas of immigration to Ukraine by categories of immigrants (region-wise): workers of science and culture - 280; highly qualified specialists and workers - 4; persons who have made a foreign investment in the economy of Ukraine - without restrictions; persons who are full brothers or sisters, grandparents, grandson or granddaughter of citizens of Ukraine -875 ; persons who were previously citizens of Ukraine - 498; parents, husband (wife) of an immigrant and his minor children - 2,070; persons who have continuously resided on the territory of Ukraine for three years from the date 
ENTREPRENEURSHIP AND SUSTAINABILITY ISSUES

ISSN 2345-0282 (online) http://jssidoi.org/jesi/

2021 Volume 8 Number 3 (March)

http://doi.org/10.9770/jesi.2021.8.3(26)

Make your research more visible, join the Twitter account of ENTREPRENEURSHIP AND SUSTAINABILITY ISSUES: @Entrepr69728810

of establishing their status as a victim of human trafficking - 41; and in total for all categories $-3,768$ people (On establishing an immigration quota for 2019 (2019)). These quotas are formed by categories of immigrants and on a regional basis (taking into account the current demographic situation) in accordance with the proposals of central and local executive bodies.

Such proposals are based on the results of the analysis of the immigration process in the previous calendar year and take into account the need to limit the quota of immigration to Ukraine of foreigners and stateless persons from the countries of origin of a significant number of illegal migrants (About the statement of the Order of formation of the immigration quota, the Order of proceedings on applications for granting of the immigration permit and representations on its cancellation and execution of the accepted decisions (2002)).

Thus, obtaining permanent residence and citizenship certificates directly depends on the availability of an immigration permit, the issuance of which is set annually by a quota. Assessing the size of the immigration quota and the principles of its formation, experts note the existence of corruption-causing factors (Immigration policy: analysis of procedures and legislative novelties in Ukraine (2019)). It is widely believed that the government should reconsider the feasibility of forming a quota and perhaps remove immigration restrictions altogether, especially for highly qualified professionals.

Often it is the existence of such quotas, which in fact are not always justified, that encourages foreigners to illegally obtain permission outside the quotas: through fictitious marriages, falsification of territorial origin or country of arrival. Immigration permit may also be granted outside the quota, but in cases limited by law. In particular, immigration permit may be granted to one of the spouses, if the other spouse, with whom he or she has been married for more than two years, is a citizen of Ukraine, children and parents of citizens of Ukraine; persons who are guardians or trustees of citizens of Ukraine, or are under the guardianship or custody of citizens of Ukraine; persons who have the right to acquire citizenship of Ukraine by territorial origin; persons whose immigration is of state interest to Ukraine; foreign Ukrainians, spouses of foreign Ukrainians, and their children in case of their joint entry and stay on the territory of Ukraine (Article 4 of the Law "On Immigration").

For permanent residence in Ukraine, a foreigner must obtain an immigration permit. Annually, 22-25 thousand such permits were issued, but after 2014 their number decreased and in 2019 amounted to only 14.2 thousand. 285 thousand foreigners permanently reside in the country, or less than $0.7 \%$ of the population (Figure 1). 
Make your research more visible, join the Twitter account of ENTREPRENEURSHIP AND SUSTAINABILITY ISSUES: @Entrepr69728810

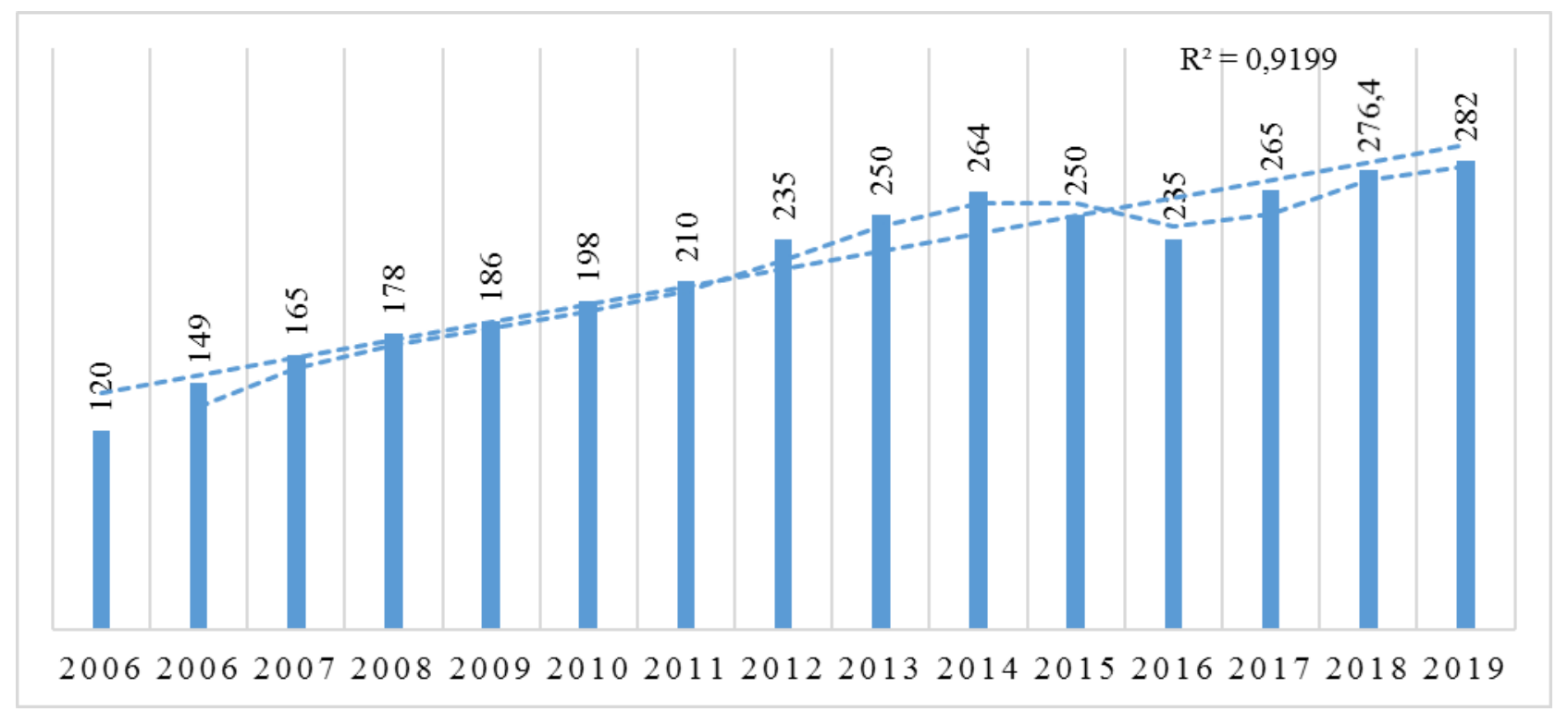

Figure 1. Number of foreigners permanently residing in Ukraine during 2005-2019, thousands of persons (using the linear filtering tool) Source: State Migration Service of Ukraine

Some foreigners stay in Ukraine temporarily, as of December 31, 2019, they amounted to 133 thousand. Most of them are students of Ukrainian higher educational institutions and temporary workers. After the decrease caused by the difficult security and economic situation, the number of foreign students in higher educational institutions of the country began to grow again and in the 2018/2019 academic year amounted to almost 55 thousand. (Figure 2). Most of them were citizens of India (19.7\%), Morocco (9.9\%), Azerbaijan (8.2\%) and Tajikistan (5.3\%). Medical and pharmacological education is the most popular education. 
Make your research more visible, join the Twitter account of ENTREPRENEURSHIP AND SUSTAINABILITY ISSUES: @Entrepr69728810

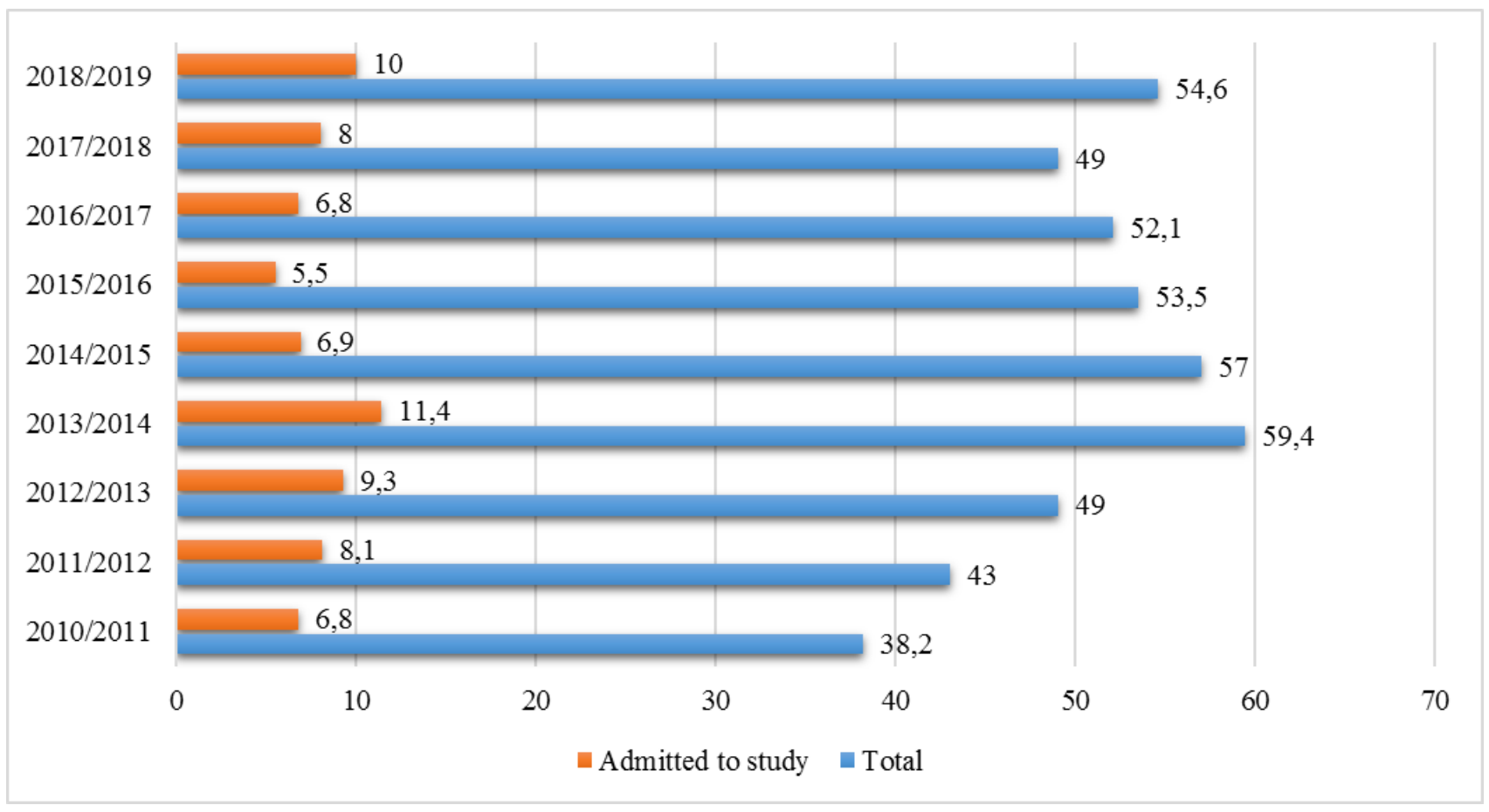

Figure 2. Foreign students in higher education institutions in Ukraine, thousands of persons Source: State Statistics Service of Ukraine

The State Employment Service, which issues work permits for foreigners, registered 16 thousand foreign workers in 2018 (Figure 3). Immigrant workers are mainly directors and managers engaged in trade and repair, industry, information and telecommunications. In 2018, the most numerous among them were citizens of Turkey (about 3 thousand), the Russian Federation (1.6 thousand), China and Belarus (about 1 thousand). 
Make your research more visible, join the Twitter account of ENTREPRENEURSHIP AND SUSTAINABILITY ISSUES: @Entrepr69728810

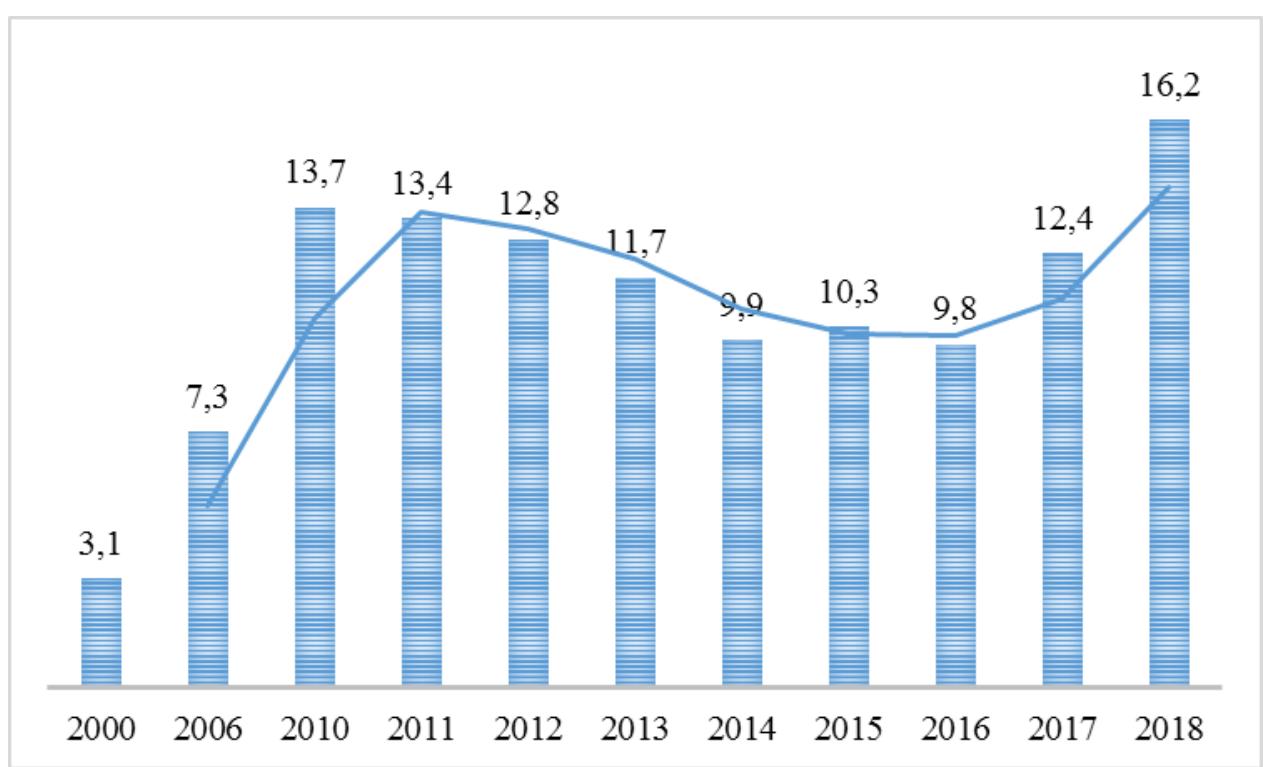

Figure 3. Number of foreigners who temporarily worked in Ukraine with an employment permit at the end of the year, thousands of persons

Source: Ministry of Social Policy of Ukraine

Another group of foreigners in Ukraine are refugees and persons who have been granted subsidiary protection. As of December 2019, 2,096 foreigners with the appropriate status resided in the country. Most of them are from Afghanistan (985 people) and Syria (446 people), as well as from some CIS countries, including Armenia (188 people) and the Russian Federation (135 people).

During 2019, 1,443 applications for international protection were filed, and 93 decisions on granting refugee status or subsidiary protection were made (Figure 4). 
Make your research more visible, join the Twitter account of ENTREPRENEURSHIP AND SUSTAINABILITY ISSUES: @Entrepr69728810

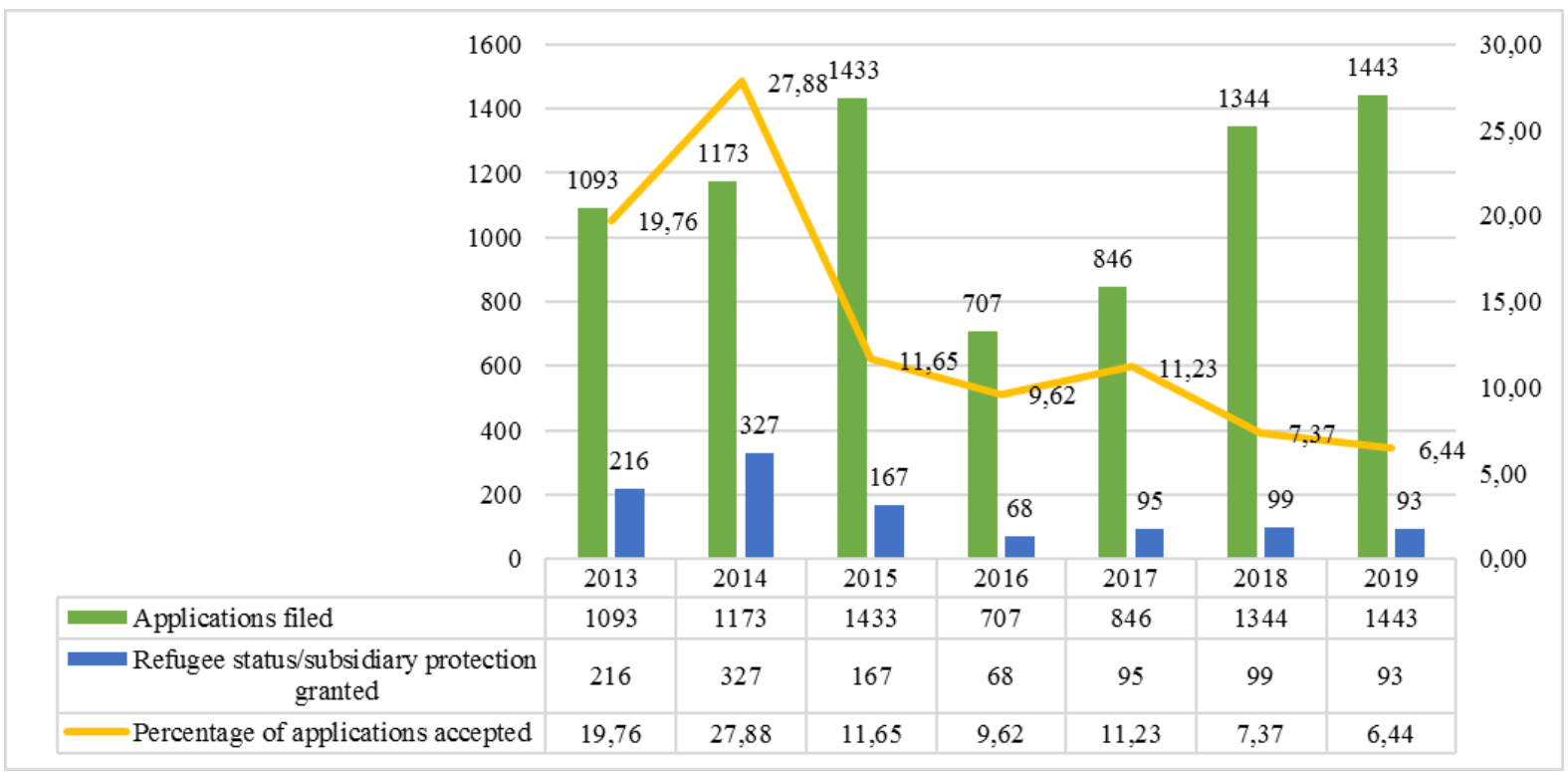

Figure 4. Number of applications for international protection and positive decisions made in Ukraine (for refugee status and subsidiary protection totally during 2014-2019)

Source: State Migration Service of Ukraine

Unregulated migration is relevant for Ukraine in two aspects. First, a certain part of Ukrainian citizens who go abroad to earn money, stay there or engage in paid activities without proper permits and documents.

Secondly, the territory of Ukraine is used for illegal transit to European countries. According to a study on labor migration conducted by the State Statistics Service in 2017, almost one in four labor migrants worked abroad without any legal status or with only a tourist visa, which is three percentage points more than in 2008 .

The simplest method of forecasting the volume of migration flows, based on statistics, is extrapolation. Extrapolation allows to provide a short-term forecast (not more than $1 / 3$ of the time period according to which data a model is built) and consist in application of the conclusions of previous observations over the intensity of migration flows to the nearest period. When applying the extrapolation method, it is assumed that the main trends of previous periods will be maintained for the forecast period.

In order to consider the constructed regression model reliable, the value of the coefficient of determination must exceed 0.5 and approach one. Construction of regression equations and calculation of the coefficient of determination are carried out using Microsoft Office Excel (Table 1). 
Make your research more visible, join the Twitter account of ENTREPRENEURSHIP AND SUSTAINABILITY ISSUES: @Entrepr69728810

Table 1. Calculations of the coefficient of determination for regression models

\begin{tabular}{|c|c|c|c|c|}
\hline \multirow{2}{*}{ Model type } & \multicolumn{2}{|c|}{ Scale of arrival } & \multicolumn{2}{c|}{ Scale of departure } \\
\cline { 2 - 5 } & Equation & 0.0173 & $y=-3,574.21+57,801$ & 0.6887 \\
\hline Linear & $y=-298.91 \mathrm{t}+34,289$ & 0.0888 & $y=53,342 \mathrm{e}^{-0.115 \mathrm{t}}$ & 0.7278 \\
\hline Exponential & $y=35,957 \mathrm{e}^{-0.024 \mathrm{t}}$ & 0.0061 & $y=-13,452 \ln (\mathrm{t})+62,828$ & 0.9066 \\
\hline Logarithmic & $y=-1,532 \ln (\mathrm{t})+36,628$ & 0.0452 & $y=910,471 \mathrm{t}^{-0.709}$ & 0.7835 \\
\hline Stepped & $y=35,512 \mathrm{t}^{-0.098}$ & $\boldsymbol{R}^{2}$ & \multicolumn{2}{|c|}{ Equation } \\
\hline
\end{tabular}

Source: author's calculations based on the data of the State Migration Service of Ukraine

In the calculation, there is a weak relationship between the scale of arrival of migrants and the time factor, while the construction of the trend equation and forecasting the scale of emigration from Ukraine may take place, as the distribution of input data is more balanced. With the value of the coefficient of determination $\mathrm{R}^{2}=0.9066$, the logarithmic model of the regression equation is the closest to the input data:

$$
y=-13,452 \ln (\mathrm{t})+62,828
$$

Substituting in the above equation the time variable reflecting the following periods $(\mathrm{t}=16 ; 17 ; 18 ; 19 ; 20)$ we receive the forecast of scales of departure of labor migrants (Table 2). According to the forecast, it can be argued that while maintaining the given trend, the scale of departure of migrant workers from Ukraine will decrease in 2020-2023 and will amount to 10-12 thousand people per year.

Table 2. Forecast of the scale of labor emigration from Ukraine for the period of 2020-2023, thousands of persons

\begin{tabular}{|c|c|c|c|}
\hline Period & Time variable, $\mathbf{t}$ & Theoretical scale of arrival & Theoretical scale of departure \\
\hline 2020 & 17 & $30,560.4$ & $12,214.5$ \\
\hline 2021 & 18 & $29,835.7$ & $11,729.4$ \\
\hline 2022 & 19 & $29,128.2$ & $11,288.3$ \\
\hline 2023 & 20 & $28,437.4$ & $10,885.2$ \\
\hline
\end{tabular}

Source: author's calculations based on the data of the State Migration Service of Ukraine

There are special features of registration for such category of foreigners as refugees and persons in need of subsidiary and temporary protection. In the Law of Ukraine 'On Refugees and Persons in Need of Subsidiary or Temporary Protection', a refugee is defined as person who is not a citizen of Ukraine and, as a result of justified fears of being persecuted on the grounds of race, religion, nationality, nationality, belonging to a particular social group or political opinion, is outside the country of his or her nationality and is unable to enjoy the protection of this country or unwilling to enjoy this protection as a result of such fears or without citizenship and outside the country of his/her previous permanent residence, cannot or does not wish to return to it as a result of these fears (Law of Ukraine 'On the Legal Status of Foreigners and Stateless Persons' (2011)). 


\section{ENTREPRENEURSHIP AND SUSTAINABILITY ISSUES}

ISSN 2345-0282 (online) http://jssidoi.org/jesi/

2021 Volume 8 Number 3 (March)

http://doi.org/10.9770/jesi.2021.8.3(26)

Make your research more visible, join the Twitter account of ENTREPRENEURSHIP AND SUSTAINABILITY ISSUES: @Entrepr69728810

Separately, it should be noted that the legislator identified just a justified fear of becoming a victim of persecution as a key criterion for characterizing a refugee. This criterion is detailed in the national judicial practice (On the Judicial Practice of Considering Disputes Concerning Refugee Status and a Person in Need of Additional or Temporary Protection, Forced Return and Compulsory Expulsion of a Foreigner or a Stateless Person from Ukraine and Disputes Related to the Stay of a Foreigner and a Stateless Person in Ukraine (2009)) and consists of subjective and objective sides. The subjective side lies in the fact that a person has this fear. Fear is an evaluative judgment that indicates psychological assessment of the surrounding situation by a person. Influenced by this subjective assessment, a person decided to leave the country and became a refugee. Subjective assessment depends on a person, and what is the norm for one person may be intolerable for another. Fear is based not only on the fact that a person has personally suffered from actions that forced him or her to leave the country, i.e., this fear may arise not from the own experience of refugee, but from the experience of others (relatives, friends and other members of the same racial or social group, etc.).

The objective side is related to the existence of a justified fears of persecution and means that there is factual evidence that these fears are real. When recognizing the status of refugee, the situation in the country of origin is an evidence of the fact that subjective fears of being persecuted are justified, i.e., supported by an objective situation in the country and a history that has taken place personally with an applicant.

A person in need of subsidiary protection is recognized as not being a refugee under the Convention relating to the Status of Refugees (1951) and the Protocol relating to the Status of Refugees (1967) and national legislation, but in need of protection because the person was forced to come to Ukraine or stay in Ukraine as a result of threats to life, security or liberty in the country of origin for fear of the death penalty or torture, inhuman or degrading treatment or punishment or widespread violence in situations of international or internal armed conflict or systematic violation of human rights and is unable or unwilling to return to such country as result of these fears. Persons in need of temporary protection include foreigners and stateless persons who are massively forced to seek protection in Ukraine as a result of external aggression, foreign occupation, civil war, ethnic clashes, natural or man-made disasters or other events that disturb public order in a particular area or on all territory of the country of origin (Law of Ukraine 'On the Legal Status of Foreigners and Stateless Persons' (2011)).

The issue of subsidiary and temporary protection has arisen and has been addressed in national legislation, as noted in certain scientific studies, due to the lack of clear and understandable criteria for granting the status of refugees to third-country nationals (Mushak (2015)). However, it is difficult to agree with this, as among the sources of legal regulation there are not only national legal acts, but also international acts and sources of soft law, which are widely used in the justification of decisions of national courts.

Thus, the definition of concepts and their characteristics is contained in Council Directive 2004/83/EC of 29 April 2004 on minimum standards for the qualification and status of third-country nationals and stateless persons as refugees or otherwise in need of international protection, as well as the essence of guaranteed protection. This act stipulates that applications for the relevant status are justified if the following conditions are met: the applicant made a real attempt to substantiate his or her application; all the important facts at his disposal were provided and there was a satisfactory explanation as to any absence of other important facts; the allegations of the applicant are clear and plausible and do not contradict the specific and general information in his case; the applicant has filed his application for international protection as soon as possible if the applicant cannot prove the absence of a valid reason for filing such application; it is established that, in general, the applicant is credible (Council Directive 2004/83/EC of 29 April 2004 on minimum standards for the qualifications and status of third country nationals or 


\section{ENTREPRENEURSHIP AND SUSTAINABILITY ISSUES}

ISSN 2345-0282 (online) http://jssidoi.org/jesi/

2021 Volume 8 Number 3 (March)

http://doi.org/10.9770/jesi.2021.8.3(26)

Make your research more visible, join the Twitter account of ENTREPRENEURSHIP AND SUSTAINABILITY ISSUES: @Entrepr69728810

stateless persons as refuges or as persons who otherwise need international protection and the content of the protection granted).

Another important soft law instrument is the Directive of the European Parliament and of the Council «On common procedures for granting and withdrawing international protection», which aims to establish common procedures for granting and withdrawing international protection, which member states must follow or introduce more favorable procedures, which are comparable to those defined by the relevant directive (Directive 2013/32/EU of the European Parliament and of the Council of 26 June 2013 on common procedures for granting and withdrawing international protection.). A separate directive defines common standards and procedures applicable to the return of persons illegally staying on the territory of third countries (Law of Ukraine 'On the Single State Demographic Register and the Documents that Confirm the Citizenship of Ukraine, Identify a Person or its Special Status' (2013)).

The peculiarity of their registration is that not only persons who have been granted the status, but all those who have applied for recognition as a refugee or a person in need of subsidiary protection are subject to centralized registration and entering information into the relevant centralized information system. Therefore, it is worth examining the whole procedure of recognition as a refugee or a person in need of subsidiary protection.

The existing violations in the procedure of acquiring special legal status are evidenced by the case law and decisions of the European Court of Human Rights concerning our state. Thus, in the decision in the case of Kebe and Others v. Ukraine (Case of Kebe and Others v. Ukraine: Judgment of the European Court of Human Rights of 1 December 2017. 2552/12.), it was established that border guards did not provide an opportunity for foreigners to apply for refugee status while on board the ship, they were not provided with information on the asylum procedure in Ukraine, no duly considered their need for international protection and did not accept their applications. In addition, the decision to refuse to cross the state border to the applicants took effect immediately, which made it possible to expel or forcibly return the applicants outside Ukraine at any time, without proper consideration by the authorities of the application for a potential threat to the applicants.

As for fingerprinting of applicants for acquiring the relevant special status, it is not a fabrication of a domestic legislator. In Germany obtaining political asylum also requires that asylum seekers be photographed and fingerprinted in order to identify them (Svoboda, 2010).

There is also an opinion in the literature that migrants, stateless persons and persons seeking political asylum in Ukraine should also be subject to mandatory dactyloscopic registration, and the relevant international norms should be taken into account when determining the procedure for their registration (Svoboda, 2010).

In this regard, it should be noted that such remarks were relevant until 2011, when the current laws "On the legal status of foreigners and stateless persons", "On refugees and persons in need of subsidiary or temporary protection" were adopted. Currently, the concept of "asylum" is contained in the Constitution of Ukraine, where Article 26 stipulates that foreigners and stateless persons may be granted asylum in the order established by law, and Article 106 stipulates that the authority to make decisions on asylum in Ukraine are referred to the competence of the President. The Law of Ukraine "On the Legal Status of Foreigners and Stateless Persons" stipulates that asylum may be granted to foreigners and stateless persons in accordance with the procedure established by law (Article 7 of the Law). That is, a separate asylum law is envisaged, which we do not have. Today in Ukraine it is possible to recognize a person as a refugee, a person in need of subsidiary or temporary 
ENTREPRENEURSHIP AND SUSTAINABILITY ISSUES

ISSN 2345-0282 (online) http://jssidoi.org/jesi/

2021 Volume 8 Number 3 (March)

http://doi.org/10.9770/jesi.2021.8.3(26)

Make your research more visible, join the Twitter account of ENTREPRENEURSHIP AND SUSTAINABILITY ISSUES: @Entrepr69728810

protection, for such persons a separate special legal status is established. Therefore, when publicistic and political sources refer to political asylum, they most likely mean the status of refugees, a person in need of subsidiary or temporary protection.

At the same time, the case law indicates that legislative provisions are not always literally implemented in law enforcement activities. Thus, the decision of the Administrative Court of Cassation of the Supreme Court in case №815/476/17 cites the provisions of the above law on the grounds for loss of refugee status. It is noted that a similar norm is enshrined in the Convention relating to the Status of Refugees (1951), according to which the provisions of this Convention do not apply to persons who have voluntarily re-used the protection of the country of citizenship (nationality).

The court also cited paragraphs 118, 119 of the Guidelines on Procedures and Criteria for Determining Refugee Status of the Office of the High Commissioner for Refugees (UN): "voluntary resumption of the protection of the country of one's nationality" means that a refugee who has voluntarily re-used the protection of the country of his or her citizenship does not need international protection. In this case, the above provision on termination of status must meet three conditions: 1) voluntariness: a refugee must act voluntarily; 2) intention: a refugee must intend to take action to re-use the protection of the country of his or her citizenship; 3) renewal: a refugee must really obtain such protection (Case №815/476/17: Decision of the Administrative Court of Cassation of the Supreme Court of 17.10. 2018).

However, in support of its decision, the court states that in determining whether refugee status has been lost in such circumstances, it is necessary to distinguish between the actual use of the protection of the country of citizenship and accidental, insignificant contacts with the authorities of this country. If a refugee has applied for, receives or renews a national passport, this will indicate, in the absence of evidence to the contrary, that he or she intends to use the protection of the country of his or her citizenship. On the other hand, obtaining certain documents from the authorities of a country, which should also be sought by persons of another citizenship, for example, birth or marriage certificates, or other similar services, cannot be considered as a renewal of the protection of that country. A refugee seeking protection from the authorities of the country of his or her citizenship may be considered to have resumed the use of protection only if such protection has actually been granted to him or her (Case № 815/476/17: Decision of the Administrative Court of Cassation of the Supreme Court of 17.10. 2018).

\section{Discussion}

Ukraine has a well-developed system for collecting information on migration. Its main sources are current migration records, censuses, household surveys, and administrative data.

A number of state registers have been created, covering certain groups of the population and containing data that could potentially be used to supplement knowledge about migration. However, the disadvantages of migration data are their lack of comparability not only with international data, but also with administrative data of various agencies, under-registration or double-entry of migrants.

In order to provide the sound statistical and factual basis needed to make appropriate migration policy decisions, it is necessary to:

to provide a block of questions related to migration (permanent, labor, circular) in the 2020 census; 
ENTREPRENEURSHIP AND SUSTAINABILITY ISSUES

ISSN 2345-0282 (online) http://jssidoi.org/jesi/

2021 Volume 8 Number 3 (March)

http://doi.org/10.9770/jesi.2021.8.3(26)

Make your research more visible, join the Twitter account of ENTREPRENEURSHIP AND SUSTAINABILITY ISSUES: @Entrepr69728810

add standardized modules on migration to household and labor force surveys to collect information on labor migration abroad, reintegration of returnees, level of integration of immigrants;

ensure compliance of migration data collected and published in Ukraine with UN recommendations on migration statistics and indicators used by Eurostat;

identify opportunities to use new sources of statistical information, such as state registers containing population data, big data;

to strengthen the level of interaction between agencies in order to achieve comparability of administrative data; to strengthen the role of the State Statistics Service of Ukraine in coordinating and methodological support for the work of departments of executive bodies responsible for administrative data in the area of migration;

in order to achieve these goals, develop and implement an integrated strategy to improve migration data.

\section{Conclusions}

One of the problems of migration control in Ukraine is the imperfection of the procedure for registration of citizens at the place of residence, which does not meet the state need to control the processes of population movement and migration within the country. Currently, the basis for registration is not the fact of living in a dwelling, but rather the right to reside in it, as the registration procedure involves the submission of supporting documents for such right.

Moreover, living of citizens without registration of residence is an offense and entails the occurrence of administrative liability, while living outside the place of registration is legal. All this condition a situation where individuals are forced to register not where they actually live, but where they can document the right to residence, which leads to the accumulation in the registers of local communities of information about the place of residence, which is not true. The solution to this problem is seen through the change of the very principle of registration from the permit to the notification, when the citizen only notifies the relevant authorities about his place of residence.

The only case in law where registration of residence is carried out by notification is acquiring the status of a forcibly displaced person, when the applicant declares a new address, which is his place of residence, without the need to provide any evidence or obtain residence permits.

Another practical problem that needs to be solved by law is to regulate the registration of residence of persons registered in the temporarily occupied territories of Donetsk or Luhansk regions, as well as Crimea, who are internally displaced persons, as well as internal migrants who migrated before 2014, but did no change the place of registration, as well as students who studied in higher educational institutions of Ukraine and were registered for the period of study. All of the above categories of persons have problems with registration and access to all administrative services provided at the place of registered residence.

The normative solution to this problem may consist in establishing a body and regulating the mechanism of registration of residence of a person in the temporarily occupied territory, as well as entering information about the place of residence of such persons in the register of territorial communities by unifying the procedures of registration of internally displaced persons and registration at the place of residence. However, currently a kind of solution to this problem of registration at the place of residence is the activity of law enforcement agencies, which are the bodies of the migration service, which do not record the place of registration of an individual when 
ENTREPRENEURSHIP AND SUSTAINABILITY ISSUES

ISSN 2345-0282 (online) http://jssidoi.org/jesi/

2021 Volume 8 Number 3 (March)

http://doi.org/10.9770/jesi.2021.8.3(26)

Make your research more visible, join the Twitter account of ENTREPRENEURSHIP AND SUSTAINABILITY ISSUES: @Entrepr69728810

exchanging a passport due to unfitness for further use, or obtaining the first passport upon reaching 16 years of age in the form ID-cards.

Migration control concerning the so-called transit migration in Ukraine is mainly related to the system of restrictions and measures of responsibility for non-compliance with established norms, and at the same time it is more important to ensure the legal stay of foreign citizens in the country, proper legal regulation of their accounting. Instead, the national case law and judgments of the European Court of Human Rights concerning our country indicate existing violations in the procedure of state protection of the rights and freedoms of foreigners and stateless persons, which they are entitled to in accordance with international standards and national legislation while staying on the territory of Ukraine.

\section{References}

About the statement of the Order of formation of the immigration quota, the Order of proceedings on applications for granting of the immigration permit and representations on its cancellation and execution of the accepted decisions (2002). Available at: https://zakon.rada.gov.ua/laws/show/1983-2002-п?lang=en\#Text

Belevtseva, V.V. (2019). Migration regime of stay of foreign citizens and stateless persons on the territory of Ukraine: state and prospects. Information and law, 2(29), 167-171.

Case №815 / 476/17: Decision of the Administrative Court of Cassation of the Supreme Court of 17.10. 2018. Available at: http://reyestr.court.gov.ua/Review/77197810

Case of Kebe and Others v. Ukraine: Judgment of the European Court of Human Rights of 1 December 2017. 2552/12. Government courier. № 109 dated 2017-06-15. P.12

Chehabeddine, M., Tvaronavičienė, M. 2020. Securing regional development. Insights into Regional Development, 2(1), $430-442$. http://doi.org/10.9770/IRD.2020.2.1(3)

Council Directive 2004/83/EC of 29 April 2004 on minimum standards for the qualifications and status of third country nationals or stateless persons as refuges or as persons who otherwise need international protection and the content of the protection granted. Available at: https://eur-lex.europa.eu/legal-content/EN/TXT/?uri=celex\%3A32004L0083

Directive 2013/32/EU of the European Parliament and of the Council of 26 June 2013 on common procedures for granting and withdrawing international protection. Available at: https://eur-lex.europa.eu/legal-content/en/ALL/?uri=celex\%3A32013L0032

Hrabylnikov, A.V. (2015). Constitutional legal status and legal regime of foreigners and stateless persons in Ukraine: correlation of concepts. Aktualni problemy vitchyznianoi yurysprudentsii, 6, 59-66.

Hula I.L. (2018). Personal expression from Ukraine of foreigners and universal membersas a west of administrative approach. Porivnialnoanalitychne pravo, 4, 252-255.

Immigration policy: analysis of procedures and legislative novelties in Ukraine (2019). Available at: https://www.slideshare.net/EWBUkraine/ss-147973898

Law of Ukraine 'On Immigration' (2001). Available at: https://zakon.rada.gov.ua/laws/show/2491-14?lang=en\#Text

Law of Ukraine 'On the Legal Status of Foreigners and Stateless Persons' (2011). Available at: https://zakon.rada.gov.ua/laws/show/3773$\underline{17 \text { ?lang=en\#Text }}$ 


\section{ENTREPRENEURSHIP AND SUSTAINABILITY ISSUES}

ISSN 2345-0282 (online) http://jssidoi.org/jesi/

2021 Volume 8 Number 3 (March)

http://doi.org/10.9770/jesi.2021.8.3(26)

Make your research more visible, join the Twitter account of ENTREPRENEURSHIP AND SUSTAINABILITY ISSUES: @Entrepr69728810

Law of Ukraine 'On the Single State Demographic Register and the Documents that Confirm the Citizenship of Ukraine, Identify a Person or its Special Status' (2013). Available at: https://zakon.rada.gov.ua/laws/show/5492-17?lang=en\#Text

Levenets, A.V. (2017). Municipal legal status of foreigners in Ukraine. The thesis for the degree of candidate of legal sciences, specialty 12.00.02. Karazin Kharkiv National University, Kharkiv. Available at: http://dspace.univer.kharkov.ua/bitstream/123456789/12602/6/dissLevenec.pdf

Lincényi, M., \& Laczko, M. 2020. Influence of Brexit on Education towards Europeanism. Insights into Regional Development, 2(4), 814824. http://doi.org/10.9770/IRD.2020.2.4(7)

Ministry of Social Policy of Ukraine. Available at: https://www.msp.gov.ua/

Mushak, N.B. (2015). Common policy of the European Union to provide protection to third-country nationals. Journal of Kyiv University of Law, 3, 346-249.

On establishing an immigration quota for 2019 (2019). Available at: https://zakon.rada.gov.ua/laws/show/114-2019-p?lang=en\#Text

On the Judicial Practice of Considering Disputes Concerning Refugee Status and a Person in Need of Additional or Temporary Protection, Forced Return and Compulsory Expulsion of a Foreigner or a Stateless Person from Ukraine and Disputes Related to the Stay of a Foreigner and a Stateless Person in Ukraine (2009). Available at: https://ips.ligazakon.net/document/AS090107

Reznik, O., Muzychuk, O., Andriichenko, N., Yakushchenko, Y., \& Korzh, S. (2020). Fight Against Doping: Experience of Ukraine and European States. Amazonia Investiga, 9(27), 34-41. https://doi.org/10.34069/AI/2020.27.03.4

State Migration Service of Ukraine. Available at: https://dmsu.qov.ua/divalnist/statistichni-dani/statistika-z-osnovnoi-diyalnosti.html

State Statistics Service of Ukraine. Available at: http://www.ukrstat.gov.ua

Svoboda, E.Yu. (2010). Some aspects of legal regulation of dactyloscopic registration. Bulletin of the Academy of Advocacy of Ukraine, 3 (19), 148-153.

Turetska, Y. (2018). Theoretical and practical aspects of the constitutional and legal status of refugees in Ukraine. Visegrad Journal on Human Rights, 2, 126-131.

Tymchyk, G.S. (2014). Administrative and legal status of foreigners and refugees in Ukraine: a comparative legalanalysis. Legal scientific electronic journal, 2, 82-84.

Vasylchenko, O.P. (2014). Features of the 1 egal status of foreigners and stateless persons while ensuring the principle of equality of rights and freedoms in Ukraine. European perspectives, 10, 23-28. 


\section{ENTREPRENEURSHIP AND SUSTAINABILITY ISSUES}

ISSN 2345-0282 (online) http://jssidoi.org/jesi/

2021 Volume 8 Number 3 (March)

http://doi.org/10.9770/jesi.2021.8.3(26)

Make your research more visible, join the Twitter account of ENTREPRENEURSHIP AND SUSTAINABILITY ISSUES: @Entrepr69728810

Kostiantyn BUHAICHUK, Doctor of Legal Sciences, Associate Professor, Kharkiv National University of Internal Affairs, Ukraine ORCID ID: orcid.org/0000-0003-2429-5010

Nataliia VARENIA, PhD, National Academy of Security Service of Ukraine, Ukraine

ORCID ID: orcid.org/0000-0002-2797-197X

Vitalii KHODANOVYCH, PhD in Law, Leading Research Associate, National Academy of the Security Service of Ukraine ORCID ID: orcid.org/0000-0002-0383-1788

Maryna KRIEPAKOVA, PhD in Law, Kharkiv National University of Internal Affairs, Ukraine

ORCID ID: orcid.org/0000-0001-5705-5027

Valentyn SEREDYNSKYI, Investigator of the Department of Investigation of Crimes in the Sphere of Transport of the Investigative Department of the DVP GUNP in Dnipropetrovsk region, Ukraine

ORCID ID: orcid.org/0000-0003-5318-2548

Copyright (C) 2021 by author(s) and VsI Entrepreneurship and Sustainability Center

This work is licensed under the Creative Commons Attribution International License (CC BY).

http://creativecommons.org/licenses/by/4.0/

(c) (1) Open Access 